\title{
RAPID DETERMINATION OF THE IMMOBILIZATION CONDITIONS FOR LEAD AND CADMIUM IN SOIL USING 2, 4, 6-TRIMERCAPTOTRIAZINE, TRISODIUM SALT, NONAHYDRATE
}

\author{
Ke JIANG ${ }^{\star}$, Kanggen $\mathrm{ZHOU}^{2}$, Jiangsheng $\mathrm{ZHANG}^{3}$ \\ ${ }^{1}$ Changsha Environmental Protection Vocational College, 410004 Changsha, China \\ 2, ${ }^{3}$ School of Metallurgy and Environment, Central South University, 410083 Changsha, China
}

Received 28 August 2017; accepted 26 June 2019

\begin{abstract}
Chemical immobilization is widely used for remediation of heavy metal contaminated soils. The present study proposed a method for the immobilization of lead $(\mathrm{Pb})$ and cadmium $(\mathrm{Cd})$ in soil using 2, 4, 6-trimercaptotriazine, trisodium salt, nonahydrate (TMT). Simulation tests were performed in an aqueous solution to rapidly screen the operational conditions. The effects of TMT dosage, reaction $\mathrm{pH}$, and the coordination ions $\left(\mathrm{Al}^{3+}, \mathrm{Fe}^{3+}\right)$ on immobilization, and the thermodynamics for the TMT-DTPA-Zn-Pb- $\mathrm{H}_{2} \mathrm{O}$ system, were investigated. The results showed that the immobilization efficiencies of $\mathrm{Pb}$ and $\mathrm{Cd}$ were removed effectively via the addition of TMT and $\mathrm{Fe}^{3+}$ in the solution containing DTPA. $\mathrm{Pb}$ and $\mathrm{Cd}$ concentrations decreased from $50 \mathrm{mg} / \mathrm{L}$ to $<3.9 \mathrm{mg} / \mathrm{L}$ and $1.4 \mathrm{mg} / \mathrm{L}$, with a $\mathrm{Fe}^{3+} / \mathrm{DTPA}$ molar ratio of 0.8 to 2.1 , and a TMT dosage of $1.0 \mathrm{~mol} / \mathrm{mol}(\mathrm{Pb}$ and $\mathrm{Cd})$. The screened results in the aqueous solution were used to immobilize $\mathrm{Pb}$ and $\mathrm{Cd}$ in soil. The extractable concentrations of $\mathrm{Pb}$ and $\mathrm{Cd}$ in the immobilized soil decreased to $19.6 \mathrm{mg} / \mathrm{kg}$ and $1.7 \mathrm{mg} / \mathrm{kg}$, respectively, with a TMT dosage of $2.2 \mathrm{~mol} / \mathrm{mol}\left(\mathrm{Pb}\right.$ and $\mathrm{Cd}$ ), and a Fe ${ }^{3+} / \mathrm{DTPA}$ molar ratio of 3.6. The bioavailability of $\mathrm{Pb}$ and $\mathrm{Cd}$ met the environmental quality standard for drylands in China (GB 15618-1995). The results demonstrated that remediation conditions could be rapidly screened in an aqueous solution rather than soil. The method using TMT and ferric sulfate was potentially effective in immobilizing $\mathrm{Pb}$ and $\mathrm{Cd}$.
\end{abstract}

Keywords: chemical immobilization, screen, stability, simultaneous, coordination, thermodynamics.

Online supplementary material: Supporting information for this paper is available as online supplementary material at https://doi.org/10.3846/jeelm.2019.11365

\section{Introduction}

Large amounts of heavy metals contained within wastewater and waste residual materials permeate into soil during mining and smelting processes (Pourret et al., 2016; Min, Wang, Chai, Yang, \& Liao, 2017), causing serious health risks for humans and ecological risks for the environment (Yang et al., 2016; Li, Ma, van der Kuijp, Yuan, \& Huang, 2014; Khan, Cao, Zheng, Huang, \& Zhu, 2008). Thus, it is necessary to immobilize the metals such as lead $(\mathrm{Pb})$ and cadmium $(\mathrm{Cd})$ in soil.

Chemical immobilization has been widely studied as a potentially reliable and cost-effective remediation technique, and various chemical amendments have been screened (Ashrafi, Mohamad, Yusoff, \& Hamid, 2014; Chiochetta et al., 2016; Lahori et al., 2017; Radziemska, Gusiatin, \& Bilgin, 2017; Wu, Zhao, Liu, Fan, \& Li, 2013; Yuan, Chai, Z. Yang, \& W. Yang, 2017). Heavy metals are immobilized by solid-liquid reactions or solid-solid reactions, including adsorption, precipitation, co-precipitation, and chelation (Basta \& McGowen, 2004; Bolan et al., 2014; Zhang et al., 2014). A lengthy contact time is required for these reactions, due to the slow reaction rate between the amendments and soil. Therefore, the chemical immobilization process takes several months to screen the amendments and operational conditions.

2,4,6-trimercaptotriazine, trisodium salt, nonahydrate (TMT) is an organic sulfur compound, which can combine with heavy metals by chelate precipitation. TMT has been widely used in the treatment of wastewater containing heavy metals (Henke, Robertson, Krepps, \& Atwood, 2000; Matlock, Henke, Atwood, Robertson, 2001; Blais, Djedidi, Cheikh, Tyagi, \& Mercier, 2008). However, studies on the application of TMT as amendments for soil remediation have received little attention.

The extracting agents used for the bioavailability analysis of heavy metals generally involve DTPA (diethylenetriaminepentaacetic acid) and EDTA. The mobilized heavy

${ }^{*}$ Corresponding author. E-mail: j_k8663661@126.com 
metals in soils can be leached in the presence of extracting agents (Bolan et al., 2014). Therefore, immobilization efficiency is determined by the equilibrium between the amendments, the heavy metals, and the extracting agents.

In this paper, we used TMT as a chemical amendment to precipitate with $\mathrm{Pb}$ and $\mathrm{Cd}$. We conducted a series of simulation immobilization tests in an aqueous solution, instead of in soil, to screen the operational conditions quicker. The effects of TMT dosage, reaction $\mathrm{pH}$, and the coordination ions $\left(\mathrm{Al}^{3+}, \mathrm{Fe}^{3+}\right)$ on immobilization were investigated. The thermodynamic equilibrium for the TMT-DTPA-Zn- $\mathrm{Pb}-\mathrm{H}_{2} \mathrm{O}$ system was also studied. Then we conducted the immobilization tests in contaminated soil to validate the applicability of the results obtained in the aqueous solution.

Table 1. Thermodynamic Data for the TMT-DTPA-Pb-Cd- $\mathrm{H}_{2} \mathrm{O}$ System $\left(25^{\circ} \mathrm{C}\right)$

\begin{tabular}{|c|c|c|}
\hline $\begin{array}{l}\text { Reaction } \\
\text { numbers }\end{array}$ & $\begin{array}{l}\text { Equilibrium } \\
\text { reactions }\end{array}$ & $\begin{array}{c}\log K \\
\text { (Sommers \& } \\
\text { Lindsay, 1979; } \\
\text { Bailey et al., 2001) }\end{array}$ \\
\hline (1) & $\mathrm{DTPA}^{5-}+\mathrm{H}^{+} \rightleftharpoons \mathrm{HDTPA}^{4-}$ & 10.45 \\
\hline$(2)$ & $\mathrm{DTPA}^{5-}+2 \mathrm{H}^{+} \rightleftharpoons \mathrm{H}_{2} \mathrm{DTPA}^{3-}$ & 18.98 \\
\hline (3) & $\mathrm{DTPA}^{5-}+3 \mathrm{H}^{+} \rightleftharpoons \mathrm{H}_{3} \mathrm{DTPA}^{2-}$ & 23.26 \\
\hline$(4)$ & $\mathrm{DTPA}^{5-}+4 \mathrm{H}^{+} \rightleftharpoons \mathrm{H}_{4} \mathrm{DTPA}^{-}$ & 25.91 \\
\hline (5) & $\mathrm{DTPA}^{5-}+5 \mathrm{H}^{+} \rightleftharpoons \mathrm{H}_{5} \mathrm{DTPA}$ & 27.73 \\
\hline (6) & $\mathrm{DTPA}^{5-}+\mathrm{Cd}^{2+} \rightleftharpoons \mathrm{CdDTPA}^{3-}$ & 19.00 \\
\hline (7) & $\begin{array}{l}\mathrm{DTPA}^{5-}+\mathrm{Cd}^{2+}+\mathrm{H}^{+} \rightleftharpoons \\
\text { CdHDTPA }^{2-}\end{array}$ & 23.17 \\
\hline$(8)$ & $\mathrm{DTPA}^{5-}+2 \mathrm{Cd}^{2+} \rightleftharpoons \mathrm{Cd}_{2} \mathrm{DTPA}^{-}$ & 21.30 \\
\hline (9) & $\mathrm{DTPA}^{5-}+\mathrm{Pb}^{2+} \rightleftharpoons \mathrm{PbDTPA}^{3-}$ & 18.66 \\
\hline$(10)$ & $\begin{array}{l}\mathrm{DTPA}^{5-}+\mathrm{Pb}^{2+}+\mathrm{H}^{+} \rightleftharpoons \\
\text { PbHDTPA }^{2-}\end{array}$ & 23.18 \\
\hline (11) & $\mathrm{DTPA}^{5-}+2 \mathrm{~Pb}^{2+} \rightleftharpoons \mathrm{Pb}_{2} \mathrm{DTPA}^{-}$ & 22.07 \\
\hline$(12)$ & $\mathrm{DTPA}^{5-}+\mathrm{Fe}^{3+} \rightleftharpoons \mathrm{FeDTPA}^{2-}$ & 27.30 \\
\hline (13) & $\begin{array}{l}\mathrm{DTPA}^{5-}+\mathrm{Fe}^{3+}+\mathrm{H}^{+} \rightleftharpoons \\
\text { FeHDTPA }^{-}\end{array}$ & 30.86 \\
\hline (14) & $\begin{array}{l}\mathrm{DTPA}^{5-}+\mathrm{Fe}^{3+}+\mathrm{H}_{2} \mathrm{O} \rightleftharpoons \\
\text { FeOHDTPA }^{3-}+\mathrm{H}^{+}\end{array}$ & 17.42 \\
\hline$(15)$ & $\mathrm{DTPA}^{5-}+\mathrm{Al}^{3+} \rightleftharpoons \mathrm{AlDTPA}^{2-}$ & 18.70 \\
\hline$(16)$ & $\begin{array}{l}\mathrm{DTPA}^{5-}+\mathrm{Al}^{3+}+\mathrm{H}^{+} \rightleftharpoons \\
\text { AlHDTPA }^{-}\end{array}$ & 23.00 \\
\hline$(17)$ & $\begin{array}{l}\mathrm{DTPA}^{5-}+\mathrm{Al}^{3+}+\mathrm{H}_{2} \mathrm{O} \rightleftharpoons \\
\mathrm{AlOHDTPA}^{3-}+\mathrm{H}^{+}\end{array}$ & 11.30 \\
\hline$(18)$ & $\mathrm{TMT}^{3-}+\mathrm{H}^{+} \rightleftharpoons \mathrm{HTMT}^{2-}$ & 11.38 \\
\hline (19) & $\mathrm{HTMT}^{2-}+\mathrm{H}^{+} \rightleftharpoons \mathrm{H}_{2} \mathrm{TMT}^{-}$ & 8.36 \\
\hline$(20)$ & $\mathrm{H}_{2} \mathrm{TMT}^{2-}+\mathrm{H}^{+} \rightleftharpoons \mathrm{H}_{3} \mathrm{TMT}$ & 5.71 \\
\hline
\end{tabular}

\section{Materials and methods}

\subsection{Simulating immobilization in an aqueous solution}

The synthetic wastewater was prepared with lead nitrate and cadmium nitrate (analytical grade). The total concentrations of $\mathrm{Pb}$ and $\mathrm{Cd}$ in the synthetic wastewater were both $50 \mathrm{mg} / \mathrm{L}$. The TMT solution (mass concentration $15 \%)$ was used as the immobilization agent. The synthetic wastewater $(50 \mathrm{~mL})$, DTPA, and TMT were mixed in a $100 \mathrm{~mL}$ plastic bottle and shaken for $2 \mathrm{~h}$ at $25^{\circ} \mathrm{C}$. The reaction $\mathrm{pH}$ was adjusted by adding $\mathrm{NaOH}$ or $\mathrm{HCl}$. The total concentrations of $\mathrm{Pb}$ and $\mathrm{Cd}$ were analyzed by ICP-AES (HJ804-2016).

To determine the influence of TMT dosage, the experiment was conducted at a DTPA to Me ( $\mathrm{Zn}$ and $\mathrm{Pb}$ ) molar ratio of $0.0-1.0$, and a reaction $\mathrm{pH}$ of $6.0 \pm 0.2$. To determine the influence of reaction $\mathrm{pH}$, the experiment was conducted at a DTPA to Me molar ratio of 1.0, and a TMT dosage of $1.0 \mathrm{~mol} / \mathrm{mol}(\mathrm{Me})$. To determine the influence of coordination ions, the experiment was conducted at a DTPA to Me molar ratio of 1.0 , a reaction $\mathrm{pH}$ of $6.0 \pm 0.2$, and a TMT dosage of $1.0 \mathrm{~mol} / \mathrm{mol}(\mathrm{Me})$. Aluminium chloride and ferric sulfate was added to supply the coordination ions $\left(\mathrm{Al}^{3+}, \mathrm{Fe} 3+\right)$.

\subsection{Thermodynamic modeling}

The equilibrium relations between the possible species for the TMT-DTPA- $\mathrm{Pb}-\mathrm{Cd}-\mathrm{H}_{2} \mathrm{O}$ system are listed in Table 1, where $\log K$ is the logarithm of the equilibrium constant $(K)$.

Equations (1)-(20) correlated the thermodynamic equilibrium constants to the molar concentrations of different complexes according to reactions (1)-(20).

$$
\begin{aligned}
& c\left(\mathrm{DTPA}^{5-}\right) \times c\left(\mathrm{H}^{+}\right) \times 10^{10.45}=c\left(\mathrm{HDTPA}^{4-}\right) ; \\
& c\left(\mathrm{DTPA}^{5-}\right) \times c\left(\mathrm{H}^{+}\right)^{2} \times 10^{18.98}=c\left(\mathrm{H}_{2} \mathrm{DTPA}^{3-}\right) ; \\
& c\left(\mathrm{DTPA}^{5-}\right) \times c\left(\mathrm{H}^{+}\right)^{3} \times 10^{23.26}=c\left(\mathrm{H}_{3} \mathrm{DTPA}^{2-}\right) ; \\
& c\left(\mathrm{DTPA}^{5-}\right) \times c\left(\mathrm{H}^{+}\right)^{4} \times 10^{25.91}=c\left(\mathrm{H}_{4} \mathrm{DTPA}^{-}\right) ; \\
& c\left(\mathrm{DTPA}^{5-}\right) \times c\left(\mathrm{H}^{+}\right)^{5} \times 10^{27.73}=c\left(\mathrm{H}_{5} \mathrm{DTPA}^{2} ;\right. \\
& c\left(\mathrm{DTPA}^{5-}\right) \times c\left(\mathrm{Cd}^{2+}\right) \times 10^{19.00}=c\left(\mathrm{CdDTPA}^{3-}\right) ;
\end{aligned}
$$

$$
c\left(\mathrm{DTPA}^{5-}\right) \times c\left(\mathrm{Cd}^{2+}\right) \times c\left(\mathrm{H}^{+}\right) \times 10^{23.17}=c\left(\mathrm{CdHDTPA}^{2-}\right) \text {; }
$$

$c\left(\mathrm{DTPA}^{5-}\right) \times c\left(\mathrm{Cd}^{2+}\right)^{2} \times 10^{21.30}=c\left(\mathrm{Cd}_{2} \mathrm{DTPA}^{-}\right) ;$

$c\left(\mathrm{DTPA}^{5-}\right) \times c\left(\mathrm{~Pb}^{2+}\right) \times 10^{18.66}=c\left(\mathrm{PbDTPA}^{3-}\right) ;$

$c\left(\mathrm{DTPA}^{5-}\right) \times c\left(\mathrm{~Pb}^{2+}\right) \times c\left(\mathrm{H}^{+}\right) \times 10^{23.18}=c\left(\mathrm{PbHDTPA}^{2-}\right)$;

$c\left(\mathrm{DTPA}^{5-}\right) \times c\left(\mathrm{~Pb}^{2+}\right)^{2} \times 10^{22.07}=c\left(\mathrm{~Pb}_{2} \mathrm{DTPA}^{-}\right) ;$

$c\left(\mathrm{DTPA}^{5-}\right) \times c\left(\mathrm{Fe}^{3+}\right) \times 10^{27.30}=c\left(\mathrm{FeDTPA}^{2-}\right) ;$

$c\left(\mathrm{DTPA}^{5-}\right) \times c\left(\mathrm{Fe}^{3+}\right) \times c\left(\mathrm{H}^{+}\right) \times 10^{30.86}=c\left(\mathrm{FeHDTPA}^{-}\right) ;$ 


$$
\begin{aligned}
& c\left(\mathrm{DTPA}^{5-}\right) \times c\left(\mathrm{Fe}^{3+}\right) \times 10^{17.42}=c\left(\mathrm{FeOHDTPA}^{2-}\right) \times c\left(\mathrm{H}^{+}\right) \\
& c\left(\mathrm{DTPA}^{5-}\right) \times c\left(\mathrm{Al}^{3+}\right) \times 10^{18.70}=c\left(\mathrm{AlDTPA}^{2-}\right) ; \\
& c\left(\mathrm{DTPA}^{5-}\right) \times c\left(\mathrm{Al}^{3+}\right) \times c\left(\mathrm{H}^{+}\right) \times 10^{23.00}=c\left(\mathrm{AlHDTPA}^{-}\right) ;
\end{aligned}
$$

$c\left(\mathrm{DTPA}^{5-}\right) \times c\left(\mathrm{Al}^{3+}\right) \times 10^{11.30}=c\left(\mathrm{AlOHDTPA}^{2-}\right) \times c\left(\mathrm{H}^{+}\right)$

$c\left(\mathrm{TMT}^{3-}\right) \times c\left(\mathrm{H}^{+}\right) \times 10^{11.38}=c\left(\mathrm{HTMT}^{2-}\right) ;$

$c\left(\mathrm{HTMT}^{2-}\right) \times c\left(\mathrm{H}^{+}\right) \times 10^{8.36}=c\left(\mathrm{H}_{2} \mathrm{TMT}^{-}\right) ;$

$c\left(\mathrm{H}_{2} \mathrm{TMT}^{-}\right) \times c\left(\mathrm{H}^{+}\right) \times 10^{5.71}=c\left(\mathrm{H}_{3} \mathrm{TMT}\right)$.

The total concentration of DTPA, Pb, Zn, and TMT, denoting $c_{\mathrm{T}, \mathrm{DTPA}}, \boldsymbol{c}_{\mathrm{T}, \mathrm{Pb}}, \boldsymbol{c}_{\mathrm{T}, \mathrm{Cd}}$ and $c_{\mathrm{T}, \mathrm{TMT}}$, was the sum of the concentrations of their complexes and free ions, as illustrated in Equations (21)-(24).

$$
\begin{aligned}
& c_{\mathrm{T}, \mathrm{DTPA}}=c\left(\mathrm{DTPA}^{5-}\right)+c\left(\mathrm{HDTPA}^{4-}\right)+c\left(\mathrm{H}_{2} \mathrm{DTPA}^{3-}\right)+ \\
& c\left(\mathrm{H}_{3} \mathrm{DTPA}^{2-}\right)+c\left(\mathrm{H}_{4} \mathrm{DTPA}^{-}\right)+c\left(\mathrm{H}_{5} \mathrm{DTPA}^{2}+\right. \\
& c\left(\mathrm{CdDTPA}^{3-}\right)+c\left[\mathrm{CdHDTPA}^{2-}\right]+c\left[\mathrm{Cd}_{2} \mathrm{DTPA}^{-}\right]+ \\
& c\left(\mathrm{PbDTPA}^{3-}\right)+c\left[\mathrm{PbHDTPA}^{-}\right]+c\left[\mathrm{~Pb}_{2} \mathrm{DTPA}^{-}\right]+ \\
& c\left(\mathrm{FeDTPA}^{2-}\right)+c\left(\mathrm{FeHDTPA}^{-}\right)+c\left(\mathrm{FeOHDTPA}^{3-}\right)+ \\
& c\left(\mathrm{AlDTPA}^{2-}\right)+c\left(\mathrm{AlHDTPA}^{-}\right)+c\left(\mathrm{AlOHDTPA}^{3-}\right) ; \\
& c_{\mathrm{T}, \mathrm{Pb}}=c\left(\mathrm{~Pb}^{2+}\right)+c\left(\mathrm{PbDTPA}^{3-}\right)+c\left[\mathrm{PbHDTPA}^{2-}\right]+ \\
& 2 c\left[\mathrm{~Pb}_{2} \mathrm{DTPA}^{-}\right] \\
& c_{\mathrm{T}, \mathrm{Cd}}=c\left(\mathrm{Cd}^{2+}\right)+c\left(\mathrm{CdDTPA}^{3-}\right)+c\left[\mathrm{CdHDTPA}^{2-}\right]+ \\
& 2 c\left[\mathrm{Cd}_{2} \mathrm{DTPA}^{-}\right] \\
& c_{\mathrm{T}, \mathrm{TMT}}=c\left(\mathrm{TMT}_{3-}\right)+c\left(\mathrm{HTMT}_{2-}\right)+c\left(\mathrm{H}_{2} \mathrm{TMT}^{-}\right)+ \\
& c\left(\mathrm{H}_{3} \mathrm{TMT}\right)
\end{aligned}
$$

The distribution of $\mathrm{TMT}^{3-}, \mathrm{Pb}^{2+}$, and $\mathrm{Zn}^{2+}$, denoting $\alpha\left(\mathrm{TMT}^{3-}\right), \alpha\left(\mathrm{Pb}^{2+}\right)$, and $\alpha\left(\mathrm{Zn}^{2+}\right)$, was defined by Equations (25)-(27).

$$
\begin{aligned}
& \alpha\left(\mathrm{TMT}^{3-}\right)=\frac{c\left(\mathrm{TMT}^{3-}\right)}{c_{\mathrm{T}, \mathrm{TMT}}} \\
& \alpha\left(\mathrm{Pb}^{2+}\right)=\frac{c\left(\mathrm{~Pb}^{2+}\right)}{c_{\mathrm{T}, \mathrm{Pb}}} ; \\
& \alpha\left(\mathrm{Cd}^{2+}\right)=\frac{c\left(\mathrm{Cd}^{2+}\right)}{c_{\mathrm{T}, \mathrm{Cd}}}
\end{aligned}
$$

Distribution of the TMT complexes in solution was determined by Equations (18)-(20) and Equations (24)-(25).

Distribution of $\mathrm{Pb}^{2+}$ and $\mathrm{Cd}^{2+}$ in solution was determined by Equations (1)-(17), Equations (21)-(23), and Equations (26)-(27), according to the following assumptions:

(a) No coordination ion exists, $c_{\mathrm{T}, \mathrm{DTPA}}=c\left(\mathrm{~Pb}^{2+}\right)=$ $c\left(\mathrm{Cd}^{2+}\right)=1 \mathrm{~mol} / \mathrm{L}$ (b) Coordination ion of $\mathrm{Al}^{3+}, c_{\mathrm{T}, \mathrm{DTPA}}=c\left(\mathrm{~Pb}^{2+}\right)=$ $c\left(\mathrm{Cd}^{2+}\right)=c\left(\mathrm{Al}^{3+}\right)=1 \mathrm{~mol} / \mathrm{L}$

(c) Coordination ion of $\mathrm{Fe}^{3+}, c_{\mathrm{T}, \mathrm{DTPA}}=c\left(\mathrm{~Pb}^{2+}\right)=$ $c\left(\mathrm{Cd}^{2+}\right)=c\left(\mathrm{Fe}^{3+}\right)=1 \mathrm{~mol} / \mathrm{L}$.

\subsection{Immobilization of the contaminated soil}

The soil was collected from a site contaminated by $\mathrm{Pb}$ milling and smelting operations in Chenzhou City, Hunan Province, China $\left(113^{\circ} 17^{\prime} 17.76^{\prime \prime} \mathrm{E}-13^{\circ} 17^{\prime} 36.07^{\prime \prime} \mathrm{E}\right.$, $\left.25^{\circ} 45^{\prime} 39.29^{\prime \prime} \mathrm{N}-25^{\circ} 46^{\prime} 1.13^{\prime \prime} \mathrm{N}\right)$. The soil samples were collected from the surface layer $(0-15 \mathrm{~cm}$ depth), and air-dried at room temperature, and then sieved through 20 mesh $(0.9 \mathrm{~mm})$. The sieved soils were digested with aqua regia for total concentration analysis of $\mathrm{Pb}$ and $\mathrm{Cd}$. The bioavailability of $\mathrm{Pb}$ and $\mathrm{Cd}$ in soil was evaluated using the extracting agent DTPA (w/w of 0.01:1 DTPAsoil). $\mathrm{Pb}$ and $\mathrm{Cd}$ concentrations were analyzed by ICPAES (HJ804-2016). Soil pH was measured by a pH meter $(\mathrm{FE} 20 \mathrm{~K})$ with a glass electrode in water (v/w of 1:2.5 $\mathrm{H}_{2} \mathrm{O}$-soil). Table 2 shows the chemical properties of the initial soils.

Table 2. Chemical properties of the initial soils

\begin{tabular}{|l|c|}
\hline \multicolumn{1}{|c|}{ Properties } & Value \pm SD \\
\hline Soil $\mathrm{pH}$ & $7.9 \pm 0.1$ \\
\hline Total concentration of $\mathrm{Pb}\left(\mathrm{mg} \cdot \mathrm{kg}^{-1}\right)$ & $1372.0 \pm 8.7$ \\
\hline Total concentration of $\mathrm{Cd}\left(\mathrm{mg} \cdot \mathrm{kg}^{-1}\right)$ & $25.2 \pm 0.3$ \\
\hline $\begin{array}{l}\mathrm{DTPA}-\mathrm{extractable} \text { concentration of } \\
\mathrm{Pb}\left(\mathrm{mg} \cdot \mathrm{kg}^{-1}\right)\end{array}$ & $547.1 \pm 5.4$ \\
\hline $\begin{array}{l}\text { DTPA-extractable concentration of } \\
\mathrm{Cd}\left(\mathrm{mg} \cdot \mathrm{kg}^{-1}\right)\end{array}$ & $17.4 \pm 0.1$ \\
\hline $\begin{array}{l}\text { Values are means } \pm \text { SEM }(n=3) \text { per group. } \\
\text { SD: standard deviation. }\end{array}$ \\
\hline
\end{tabular}

The sieved 20-mesh soils were used for immobilization treatment. The TMT solution (mass concentration 15\%) and the ferric sulfate solid were used as the remediation agents. Soil samples (200 g) were added to a $250 \mathrm{~mL}$ plastic bottle and mixed with the remediation agent at room temperature.

The experiment was carried out at a ferric sulfate dosage of $35.7 \mathrm{~g} \cdot \mathrm{kg}^{-1}$, a reaction time of $60 \mathrm{~d}$, a percentage of the field capacity of $70 \%$, and a soil $\mathrm{pH}$ of $7.6 \pm 0.2$. Soil $\mathrm{pH}$ was adjusted by adding $\mathrm{HCl}$ or $\mathrm{NaOH}$. The immobilized soil was air-dried at room temperature, and sieved through 20 mesh $(0.9 \mathrm{~mm})$. Then the bioavailability of $\mathrm{Pb}$ and $\mathrm{Cd}$ was measured.

\section{Results and discussion}

\subsection{Simulating immobilization in an aqueous solution}

\subsubsection{Influence of the TMT dosage}

Figure 1 shows the influence of TMT dosage on $\mathrm{Pb}$ and $\mathrm{Cd}$ concentrations in an aqueous solution. $\mathrm{Pb}$ and $\mathrm{Cd}$ 
concentrations decreased with increasing TMT dosage. In the absence of DTPA, $\mathrm{Pb}$ and $\mathrm{Cd}$ concentrations decreased to levels $<6.4 \mathrm{mg} / \mathrm{L}$ and $4.7 \mathrm{mg} / \mathrm{L}$, respectively, with a TMT dosage between $0.48-1.44 \mathrm{~mol} / \mathrm{mol} \mathrm{Me}(\mathrm{Zn}$ and $\mathrm{Pb}$ ). The TMT was effective for the removal of $\mathrm{Pb}$ and $\mathrm{Cd}$ in an aqueous solution. $\mathrm{Pb}$ and $\mathrm{Cd}$ concentrations decreased to levels $<34.6 \mathrm{mg} / \mathrm{L}$ and $28.6 \mathrm{mg} / \mathrm{L}$ when the DTPA to Me molar ratio was 1.0. This indicated that the mobilized $\mathrm{Pb}$ and $\mathrm{Cd}$ in the aqueous solution were leached in the presence of DTPA.

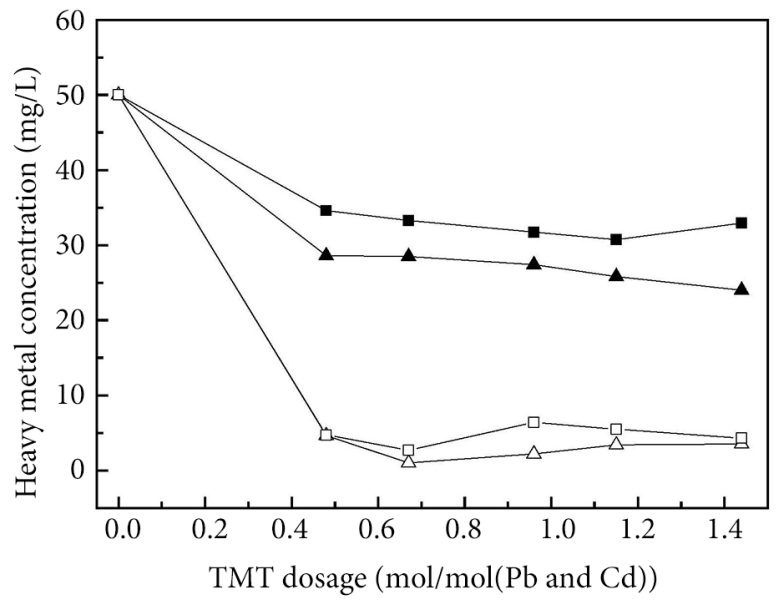

$\mathrm{DTPA} /(\mathrm{Pb}+\mathrm{Cd})$ molar ratio $=1.0 \multimap-\mathrm{Pb} \longrightarrow \mathrm{Cd}$ $\mathrm{DTPA} /(\mathrm{Pb}+\mathrm{Cd})$ molar ratio $=0.0-\square-\mathrm{Pb} \longrightarrow \triangle \mathrm{Cd}$

Figure 1. Influence of TMT dosage on $\mathrm{Pb}$ and $\mathrm{Cd}$ concentrations in an aqueous solution

\subsubsection{Influence of the reaction $p H$}

Figure 2 shows the influence of reaction $\mathrm{pH}$ on $\mathrm{Pb}$ and $\mathrm{Cd}$ concentrations in an aqueous solution. $\mathrm{Pb}$ and $\mathrm{Cd}$ concentrations decreased with increasing reaction $\mathrm{pH} . \mathrm{Pb}$ and Cd concentrations decreased to $22.3 \mathrm{mg} / \mathrm{L}$ and $27.1 \mathrm{mg} / \mathrm{L}$, respectively, at $\mathrm{pH}$ 9.0. This was caused by the distribution of the TMT complexes in solution. The possible

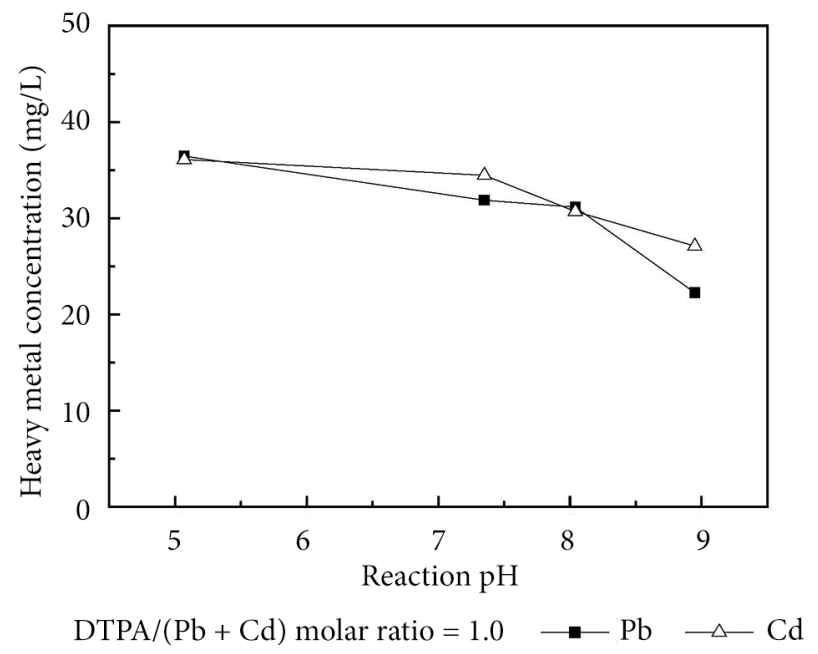

Figure 2. Influence of reaction $\mathrm{pH}$ on $\mathrm{Pb}$ and $\mathrm{Cd}$ concentrations in an aqueous solution
TMT complexes included $\mathrm{H}_{3}$ TMT, $\mathrm{H}_{2} \mathrm{TMT}^{-}$, $\mathrm{HTMT}^{2-}$, and $\mathrm{TMT}^{3-}$. The last three complexes could combine with heavy metals (Dongmei, Yunbai, Ping, \& Zhigang, 2006). As shown in Figure $\mathrm{S} 1$ (See supplemental material), $\mathrm{H}_{3} \mathrm{~T}$ MT was the dominating complex at $\mathrm{pH}$ values $<4.0$. The distribution ratio of $\mathrm{H}_{2} \mathrm{TMT}^{-}, \mathrm{HTMT}^{2-}$ and $\mathrm{TMT}^{3-}$, increased from $1.91-99.99 \%$ at a $\mathrm{pH}$ range of 4.0-9.0. Therefore, $\mathrm{Pb}-\mathrm{TMT}$ and $\mathrm{Cd}-\mathrm{TMT}$ precipitates were more stable at higher $\mathrm{pH}$, which was consistent with previous results (Matlock et al., 2001).

\subsubsection{Influence of the coordination ions}

Figure 3 shows the influence of coordination ions on $\mathrm{Pb}$ and $\mathrm{Cd}$ concentrations in an aqueous solution. Figure 4 shows the distribution of $\mathrm{Pb}^{2+}$ and $\mathrm{Cd}^{2+}$ in solution as a function of $\mathrm{pH}$. The concentrations of $\mathrm{Pb}$ and $\mathrm{Cd}$ remained stable with increasing $\mathrm{Al}^{3+}$ dosage in Figure 3. In contrast, $\mathrm{Pb}$ and $\mathrm{Cd}$ concentrations decreased to $<3.9 \mathrm{mg} / \mathrm{L}$ and 1.4 $\mathrm{mg} / \mathrm{L}$, respectively, with a $\mathrm{Fe}^{3+} / \mathrm{DTPA}$ molar ratio of 0.8 to 2.1. The immobilization efficiencies of $\mathrm{Pb}$ and $\mathrm{Cd}$ were determined by the equilibrium competition among TMT, $\mathrm{Pb}$, $\mathrm{Cd}$, and DTPA. The free ions of $\mathrm{Pb}^{2+}$ and $\mathrm{Cd}^{2+}$ favored the formation of $\mathrm{Pb}-\mathrm{TMT}$ and $\mathrm{Cd}-\mathrm{TMT}$ precipitates, while the Pb-DTPA and Cd-DTPA complexes had the opposite effect. As shown in Figure 4, 46.1\% of $\mathrm{Pb}^{2+}$ transformed into $\mathrm{Pb}$-DTPA complexes, and $12.7 \%$ of $\mathrm{Cd}^{2+}$ transformed into Cd-DTPA complexes at a $\mathrm{pH}$ range of 2.0-9.0 for the DTPA-Zn-Pb- $\mathrm{H}_{2} \mathrm{O}$ system. Therefore, TMT-Pb and TMT-Cd precipitates became unstable, and $\mathrm{Pb}$ and $\mathrm{Cd}$ concentrations increased in the presence of DTPA. Furthermore, the addition of $\mathrm{Al}^{3+}$ had little influence on the distribution ratio at a $\mathrm{pH}$ range of 2.0-9.0, while the distributions of $\mathrm{Pb}^{2+}$ and $\mathrm{Cd}^{2+}$ increased close to $100 \%$ in the presence of $\mathrm{Fe}^{3+}$. This indicated that the precipitates of $\mathrm{Pb}-\mathrm{TMT}$ and $\mathrm{Cd}-\mathrm{TMT}$ were stable via the addition of $\mathrm{Fe}^{3+}$, which decreased $\mathrm{Pb}$ and $\mathrm{Cd}$ concentrations.

The simulation tests for the TMT-DTPA-Zn-Pb- $\mathrm{H}_{2} \mathrm{O}$ system showed that TMT was effective for removal of $\mathrm{Pb}$ and $\mathrm{Cd}$. The $\mathrm{Pb}-\mathrm{TMT}$ and $\mathrm{Cd}-\mathrm{TMT}$ precipitates were

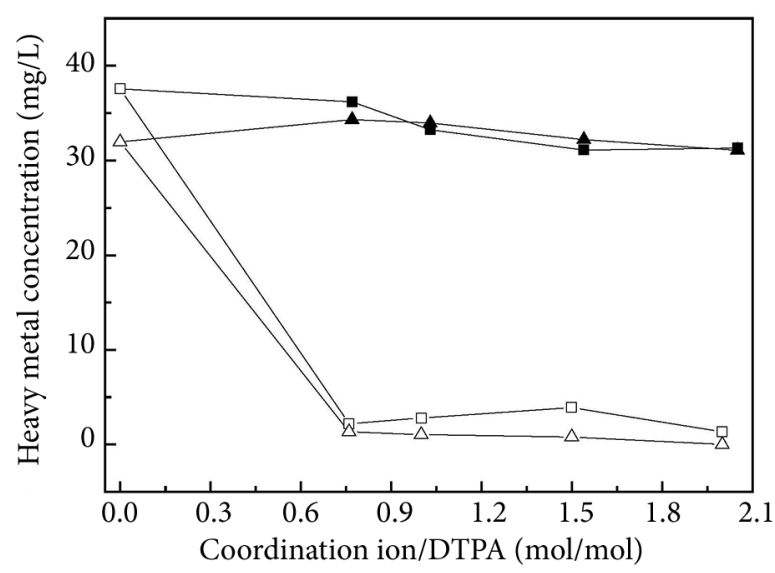

Coordination ion of $\mathrm{Al}^{3+} \longrightarrow-\mathrm{Pb} \longrightarrow \mathrm{Cd}$

Coordination ion of $\mathrm{Fe}^{3+}-\square-\mathrm{Pb} \quad-\triangle-\mathrm{Cd}$

Figure 3. Influence of coordination ions on $\mathrm{Pb}$ and $\mathrm{Cd}$ concentrations in an aqueous solution 


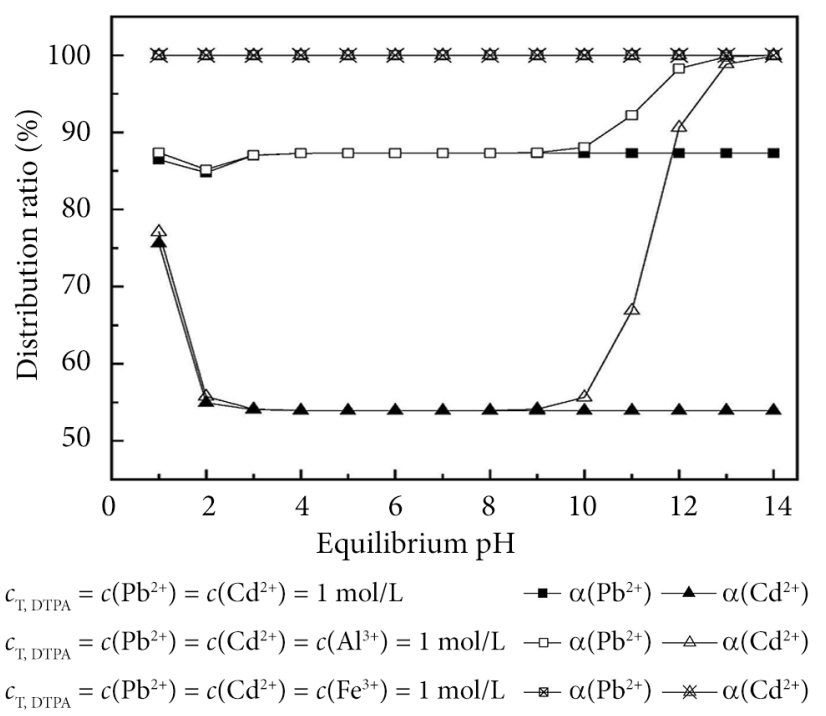

Figure 4. Distribution of $\mathrm{Pb}^{2+}$ and $\mathrm{Cd}^{2+}$ in solution as a function of $\mathrm{pH}$

more stable when $\mathrm{Fe}^{3+}$ was added in the solution containing DTPA. The operational conditions were determined rapidly by the solution tests and thermodynamic modeling, which were used to guide the immobilization of heavy metals in contaminated soils.

\subsection{Immobilization of the contaminated soil}

Figure 5 shows the bioavailability of $\mathrm{Pb}$ and $\mathrm{Cd}$ in the immobilized soils. The extractable concentrations of $\mathrm{Pb}$ and $\mathrm{Cd}$ were $<19.6 \mathrm{mg} / \mathrm{kg}$ and $1.7 \mathrm{mg} / \mathrm{kg}$, respectively, with a TMT dosage of $2.2 \mathrm{~mol} / \mathrm{mol}(\mathrm{Pb}$ and $\mathrm{Cd})$, and a $\mathrm{Fe}^{3+}$ /DTPA molar ratio of 3.6. The extractable concentrations of $\mathrm{Pb}$ and $\mathrm{Cd}$ decreased markedly via the addition of $\mathrm{Fe}^{3+}$, which was consistent with the results obtained in the aqueous solution (Figure 3). Moreover, the extractable concentrations of $\mathrm{Pb}$ and $\mathrm{Cd}$ met the environmental quality standard for drylands in China (GB 15618-1995, State Environmental Protection Administration of China

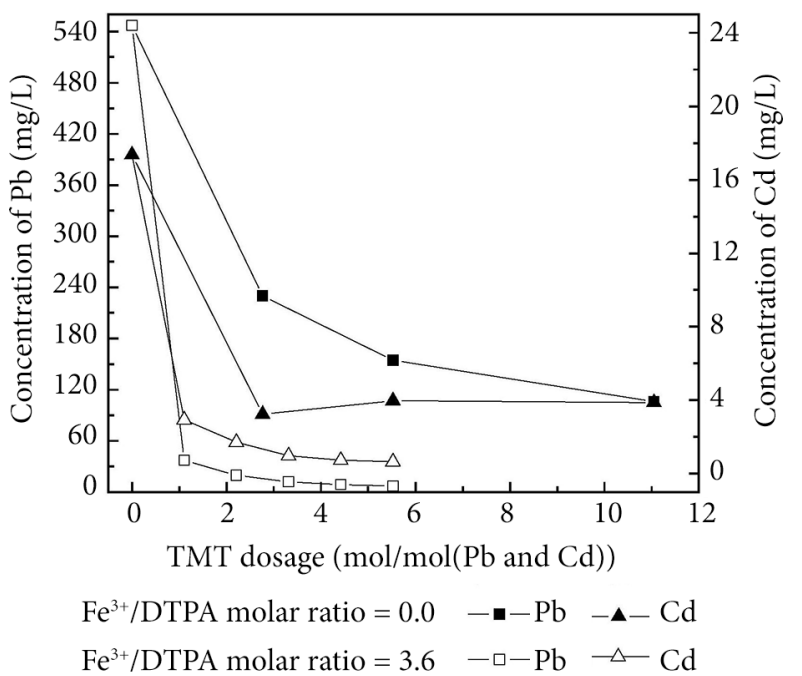

Figure 5. The bioavailability of $\mathrm{Pb}$ and $\mathrm{Cd}$ in immobilized soils
(1995)). As shown in Table S1 (See supplemental material), the approximate cost including TMT, $\mathrm{Fe}_{2}\left(\mathrm{SO}_{4}\right)_{3}$, and $\mathrm{Ca}(\mathrm{OH})_{2}$ was $\$ 80 \mathrm{US} / \mathrm{t}$ of soil, which was relatively inexpensive compared to other traditional amendments (Guo, Zhou, \& Ma, 2006; Rampley \& Ogden, 1998). These results demonstrated that the method using TMT and ferric sulfate was effective and financially viable in immobilizing $\mathrm{Pb}$ and $\mathrm{Cd}$ in contaminated soils.

\section{Conclusions}

TMT is used as the chemical amendments for immobilization of $\mathrm{Pb}$ and $\mathrm{Cd}$ in soil. To screen the operational conditions rapidly, the simulating tests in an aqueous solution and the thermodynamics for the TMT-DTPA- $\mathrm{Zn}-\mathrm{Pb}-\mathrm{H}_{2} \mathrm{O}$ system were investigated. The results show that $\mathrm{Pb}$ and $\mathrm{Cd}$ can be removed effectively via the addition of TMT and $\mathrm{Fe}^{3+}$ in the solution containing DTPA. Pb and Cd concentrations decrease to $<3.9 \mathrm{mg} / \mathrm{L}$ and $1.4 \mathrm{mg} / \mathrm{L}$, respectively, with a $\mathrm{Fe}^{3+} / \mathrm{DTPA}$ molar ratio of 0.8 to 2.1 , and a TMT dosage of $1.0 \mathrm{~mol} / \mathrm{mol}(\mathrm{Pb}$ and $\mathrm{Cd})$.

The contaminated soil was treated at a TMT dosage of $2.2 \mathrm{~mol} / \mathrm{mol}\left(\mathrm{Pb}\right.$ and $\mathrm{Cd}$ ), and $\mathrm{Fe}^{3+} / \mathrm{DTPA}$ molar ratio of 3.6. The extractable concentrations of $\mathrm{Pb}$ and Cd decrease to $19.6 \mathrm{mg} / \mathrm{kg}$ and $1.7 \mathrm{mg} / \mathrm{kg}$, respectively, which meet the environmental quality standard for drylands in China (GB 15618-1995). The method using TMT and ferric sulfate is effective for immobilization of $\mathrm{Pb}$ and $\mathrm{Cd}$ in soil. The operational conditions screened in the aqueous solution can be used to guide the immobilization of contaminated soil.

\section{Acknowledgements}

This work was supported by the National Key Technology R\&D Program of China under Grant Number 2012BAC09B00.

\section{References}

Ashrafi, M., Mohamad, S., Yusoff, I., \& Hamid, F. S. (2014). Mobilization of $\mathrm{Pb}, \mathrm{Cd}$, and $\mathrm{Zn}$ in a contaminated soil using eggshell and banana stem amendments: Metal leachability and a sequential extraction study. Environmental Science and Pollution Research, 22, 223-230.

https://doi.org/10.1007/s11356-014-3299-4

Bailey, J. R., Hatfield, M. J., Henke, K. R., Krepps, M. K., Morris, J. L., Otieno, T., \& Atwood, D. A. (2001). Transition metal complexes of 2, 4, 6-trimercapto-1, 3, 5-triazine (TMT): Potential precursors to nanoparticulate metal sulfides. Journal of Organometallic Chemistry, 623(1), 185-190. https://doi.org/10.1016/S0022-328X(00)00740-3

Basta, N. T., \& McGowen, S. L. (2004). Evaluation of chemical immobilization treatments for reducing heavy metal transport in a smelter-contaminated soil. Environmental Pollution, 127, 73-82. https://doi.org/10.1016/S0269-7491(03)00250-1

Blais, J. F., Djedidi, Z., Cheikh, R. B., Tyagi, R. D., \& Mercier, G. (2008). Metals precipitation from effluents. Practice Periodical of Hazardous, Toxic, and Radioactive Waste Management, 12(3), 135-149. 
https://doi.org/10.1061/(ASCE)1090-025X(2008)12:3(135)

Bolan, N., Kunhikrishnan A., Thangarajan, R., Kumpiene, J., Park, J., Makino, T., \& Scheckel, K. (2014). Remediation of heavy metal(loid)s contaminated soils-to mobilize or to immobilize? Journal of Hazardous Materials, 266, 141-166. https://doi.org/10.1016/j.jhazmat.2013.12.018

Chiochetta, C. G., Cotelle, S., Masfaraud, J. F., Toumi, H., Quaranta, G., Adani, F., \& Radetski, C. M. (2016). Use of agroindustrial organic sludge amendment to remediate degraded soil: Chemical and eco (geno) toxicological differences between fresh and stabilized sludge and establishment of application rates. Environmental Science and Pollution Research, 23, 3018-3025. https://doi.org/10.1007/s11356-015-5310-0

Dongmei, L., Yunbai, L., Ping, Y., \& Zhigang, C. (2006). Chemistry of copper trimercaptotriazine (TMT) compounds and removal of copper from copper-ammine species by TMT. Applied Organometallic Chemistry, 20(4), 246-253. https://doi.org/10.1002/aoc.1049

Guo, G., Zhou, Q., \& Ma, L. Q. (2006). Availability and assessment of fixing additives for the in situ remediation of heavy metal contaminated soils: A review. Environmental Monitoring and Assessment, 116(1), 513-528.

https://doi.org/10.1007/s10661-006-7668-4

Henke, K. R., Robertson, D., Krepps, M. K., \& Atwood, D. A. (2000). Chemistry and stability of precipitates from aqueous solutions of 2, 4, 6-trimercaptotriazine, trisodium salt, nonahydrate (TMT-55) and mercury (II) chloride. Water Research, 34, 3005-3013.

https://doi.org/10.1016/S0043-1354(00)00038-5

Khan, S., Cao, Q., Zheng, Y. M., Huang, Y. Z., \& Zhu, Y. G. (2008). Health risks of heavy metals in contaminated soils and food crops irrigated with wastewater in Beijing, China. Environmental Pollution, 152, 686-692. https://doi.org/10.1016/j.envpol.2007.06.056

Lahori, A. H., Zhang, Z., Guo, Z., Mahar, A., Li, R., Awasthi, M. K., \& Zhao, J. (2017). Potential use of lime combined with additives on (im) mobilization and phytoavailability of heavy metals from $\mathrm{Pb} / \mathrm{Zn}$ smelter contaminated soils. Ecotoxicology and Environmental Safety, 145, 313-323. https://doi.org/10.1016/j.ecoenv.2017.07.049

Li, Z., Ma, Z., van der Kuijp, T. J., Yuan, Z., \& Huang, L. (2014). A review of soil heavy metal pollution from mines in China: Pollution and health risk assessment. Science of the Total Environment, 468, 843-853. https://doi.org/10.1016/j.scitotenv.2013.08.090

Matlock, M. M., Henke, K. R., Atwood, D. A., \& Robertson, D. (2001). Aqueous leaching properties and environmental implications of cadmium, lead and zinc trimercaptotriazine (TMT) compounds. Water Research, 35, 3649-3655.
https://doi.org/10.1016/S0043-1354(01)00091-4

Min, X., Wang, Y., Chai, L., Yang, Z., \& Liao, Q. (2017). Highresolution analyses reveal structural diversity patterns of microbial communities in Chromite Ore Processing Residue (COPR) contaminated soils. Chemosphere, 183, 266-276. https://doi.org/10.1016/j.chemosphere.2017.05.105

Pourret, O., Lange, B., Bonhoure, J., Colinet, G., Decrée, S., Mahy, G., \& Faucon, M. P. (2016). Assessment of soil metal distribution and environmental impact of mining in Katanga (Democratic Republic of Congo). Applied Geochemistry, 64, 43-55. https://doi.org/10.1016/j.apgeochem.2015.07.012

Radziemska, M., Gusiatin, Z. M., \& Bilgin, A. (2017). Potential of using immobilizing agents in aided phytostabilization on simulated contamination of soil with lead. Ecological Engineering, 102, 490-500.

https://doi.org/10.1016/j.ecoleng.2017.02.028

Rampley, C. G., \& Ogden, K. L. (1998). Preliminary studies for removal of lead from surrogate and real soils using a water soluble chelator: Adsorption and batch extraction. Environmental Science and Technology, 32(7), 987-993.

https://doi.org/10.1021/es9706256

Sommers, L. E., \& Lindsay, W. L. (1979). Effect of pH and redox on predicted heavy metal-chelate equilibria in soils. Soil Science Society of America Journal, 43(1), 39-47. https://doi.org/10.2136/sssaj1979.03615995004300010007x

State Environmental Protection Administration of China. (1995). Chinese Environmental Quality Standard for Soils (GB 156181995).

Wu, J., Zhao, Y., Liu, L., Fan, B., Li, M. (2013). Remediation of soil contaminated with decabrominated diphenyl ether using white rot fungi. Journal of Environmental Engineering and Landscape Management, 21(3), 171-179. https://doi.org/10.3846/16486897.2012.721374

Yang, Z., Zhang, Z., Chai, L., Wang, Y., Liu, Y., \& Xiao, R. (2016). Bioleaching remediation of heavy metal-contaminated soils using Burkholderia sp. Z-90. Journal of Hazardous Materials, 301, 145-152. https://doi.org/10.1016/j.jhazmat.2015.08.047

Yuan, Y., Chai, L., Yang, Z., \& Yang, W. (2017). Simultaneous immobilization of lead, cadmium, and arsenic in combined contaminated soil with iron hydroxyl phosphate. Journal of Soils and Sediments, 17(2), 432-439.

https://doi.org/10.1007/s11368-016-1540-0

Zhang, S., Yang, Z., Wu, B., Wang, Y., Wu, R., \& Liao, Y. (2014). Removal of $\mathrm{Cd}$ and $\mathrm{Pb}$ in calcareous soils by using Na2EDTA recycling washing. CLEAN - Soil, Air, Water, 42(5), 641-647. https://doi.org/10.1002/clen.201200634 